\title{
PELATIHAN BANTUAN HIDUP DASAR BAGI SISWA SMA 1 SUMBER PUCUNG KABUPATEN MALANG
}

\author{
Kristianto Dwi Nugroho ${ }^{1}$, Ucip Sucpito ${ }^{2}$ \\ Program Studi S1 Ners STIKes Panti Waluya Malang \\ Jalan Yulius Usman No 62 \\ e-mail: kristianto.nugroho77@yahoo.co.id
}

\begin{abstract}
ABSTRAK
Bantuan hidup dasar merupakan bantuan yang diberikan saat jantung berhenti bekerja, bisa dilakukan baik di rumah sakit ataupun di luar rumah sakit. Pendidikan kesehatan mengenai bantuan hidup dasar sangat penting diketahui karena berhubungan dengan kelangsungan hidup seseorang. Sehingga dilakukan pendidikan kesehatan kepada siswa SMA N 1 Sumber Pucung, tepatnya pada siswa PMR. Diharapkan siswa PMR menjadi agent of change di masyarakat. Pendidikan kesehatan diawali dengan pengkajian permasalahan di SMA N 1 Sumberpucung. Tahap selanjutnya adalah penentuan intervensi pendidikan kesehatan berupa Bantuan Hidup Dasar. Pendidikan Kesehatan Bantuan Hidup Dasar dilakukan melalui media zoom dan pengkajian dan pendampingan dilakukan melalui media group Whatsapp. Media online dipilih karena pendidikan kesehatan ini dilakukan pada masa pandemic COVID-19, sehingga meminimalisir pertemuan dan kerumunan. Respon yang diberikan partisipan sangat positif. Siswa PMR menjadi lebih paham dan mengerti mengenai dalam melakukan pertolongan pertama dan bantuan hidup dasar. Hal tersebut dinilai dari kuesinoer evaluasi, menghasilkan damapk positif bagi siswa. Tetapi ada sedikit kekurangan, karena penkes dilakukan melalui media on-line, dalam praktik pertolongan pertama hanya diberikan melalui video, sehingga siswa tidak bisa praktik secara langsung. Pengembangan PkM selanjutnya diharapkan menggunakan media yang lebih interaktif dan dapat praktik secara langsung, supaya pemahaman siswa dapat lebih baik.
\end{abstract}

Kata Kunci : Bantuan Hidup Dasar, Pertolongan Pertama, Pendidikan Kesehatan

\begin{abstract}
Basic life support is assistance that is given when the heart stops working, it can be done either in the hospital or outside the hospital. Health education regarding basic life support is very important to know because it is related to a person's survival. So that health education is carried out to students of Senior High School 1 Sumber Pucung, to be precise for PMR students. It is hoped that PMR students will become agents of change in society. Health education begins with an assessment of the problems at Senior High School N 1 Sumberpucung. The next stage is the determination of health education interventions in the form of Basic Life Assistance. Basic Life Assistance Health Education is carried out through zoom media and assessment and assistance is carried out through the Whatsapp group media. Online media was chosen because this health education was carried out during the COVID-19 pandemic, thereby minimizing gatherings and crowds. The response given by the Philippines was very positive. PMR students become more aware and understand about doing first aid and basic life support. This is assessed from the evaluation questionnaire, resulting in a positive impact for students. But there are a few shortcomings, because the penkes are carried out through online media, in practice first aid is only given via video, so students cannot practice directly. Further development of PkM is expected to use media that is more interactive and can be practiced directly, so that students' understanding can be better.
\end{abstract}

Key Words : Basic life support; Fist Aid; Health Education

\section{PENDAHULUAN}

Bantuan hidup dasar merupakan sebuah bantuan pertama yang diberikan pekada seseorang yang mengalami henti jantung. Tindakan bantuan pada henti jantung dikondisikan untuk kejadian baik di dalam rumah sakit ataupun di luar rumah sakit. Pertolongan bantuan hidup dasar sering kali dilakukan di luar rumah sakit atau sering disebut prehospital. Pelayanan ini memang sangat 
penting bagi kelangsungan hidup seseoran (Nugroho, Soeharto and Utami, 2019). Pertolongan dilakukan sesegera mungkin di mana saja dan kapan saja, sehingga setiap orang idealnya harus memiliki kemampuan dalam memberikan pertolongan pertama (Nasution, 2017). Pendidikan kesehatan mengenai Bantuan Hidup Dasar (BHD), sangat penting diketahui semua orang, karen berhubungan dengan kelangsungan hidup seseorang (Putri, Barlianto and Setyoadi, 2019).

Oleh karena pendidikan kesehatan mengenai pertolongan pertama dan Bantun Hidup Dasar (BHD) harus diberikan sedini mungkin. Salah satu pendidikan kesehatan pada masa yang paling tepat adalah pada masa remaja. Masa remaja memiliki pertumbuhan otak yang paling sempurna, serta sistem syaraf dapat berfungsi dengan sangat baik. Kemampuan kognitif, kemampuan perumusan masalah, pengambilan kepututsan dan pemecahan masalah cukup baik bagi remaja. Sehingga masa remaja paling tepat diberikan pendidikan kesehatan mengenai BHS (Bantuan Hidup Dasar) .

Pendidikan kesehatan BHD sangat penting karena kita tidak pernah tau kapan, dimana dan siapa orang yang mengalami henti jantung. Data yang dikeluarkan oleh Word Health Organization (WHO) kematian karena henti jantung masih tinggi di dunia. Diperkirakan sekitar 350.000 orang per tahun meninggal karena hentin jantung. Sedangkan 60 persen kematian karena henti jantung. Salah satu cara menurunakan dan menyelamatkan pasien dengan henti jantung dengan cara melakukan BHD(Lontoh, Kiling and Wongkar, 2013).

Pendidikan kesehatan yang akan dilakukan kepada siswa SMAN 1 Sumber Pucung, diharapkan dapat meningkatkan pengetahuan yang dimiliki. Selain itu pendidikan ini diharapkan dapat mengatasi permasalahan mengenai ketidaktahuanmasyarakat tentang BHD, karena perlu kita ingat bahsa BHD sangat penting berkaitan dengan kelangsungan hidup seseorang. Selain itu dengan pendidikan kepada siswa SMA mengenai BHD diharapkan dapat meningkatkan kesadaran dan pengetahuan masyarakat pada umumnya mengenai pentingnya pertolongan pertama.

Sejak ditetapkan mennjadi pandemic global oleh WHO pada tanggal 11 Maret 2020, COVID-19 menjadi isu kesehatan di seluruh dunia. Pandemi virus COVID-19 ini diawali saat ditemukannya pasien penyakit demam dan pernafasan di Wuhan, Cina pada Desember 2019 (WHO, 2020). Wabah tersebut semakin menyebar sampai ke seluruh dunia termasuk Indonesia. Gejala COVID-19 yang paling umum adalah demam, batuk kering, dan kelelahan. Gejala lain yang kurang umum dan dapat mempengaruhi beberapa pasien termasuk sakit dan (Newman and Lattouf, 2020)konjungtivitis, sakit tenggorokan, diare, kehilangan rasa atau bau atau ruam pada kulit atau perubahan warna jari tangan atau kaki. Gejala-gejala ini biasanya ringan dan mulai secara bertahap. Beberapa orang menjadi terinfeksi tetapi hanya memiliki gejala yang sangat ringan (WHO, 2020).

Karena semakin bertambahnya kasus COVID-19 di seluruh dunia, maka dilakukan pembatasan aktifitas. Indonesia juga melakukan melakukan pembatasan serupa yang disebut Pembatasan Sosial Berskala Besar (PSBB). Penerapan PSBB termuat dalam Peraturan Presiden nomor 21 tahun 2020 menyatakan bahwa akan dilaksanakan peliuran sekolah, tempat kerja, kegiatan keagamaan dan pembatasan kegiatan umum (Presiden Republik Indonesia, 2020). 
Kegiatan PSBB secara langsung ataupun tidak langsung berdampak pada seluruh sektor kehidupam masyarakat, baik segi budaya hingga ekonomi. Menurunnya aktifitas masyarakat karena kegaitan pembatasan sosial mengakibatkan penurunan daya beli, dan sampai penutupan pusat-pusat perekomomian masyarakat. Dampak tersebut mangakibatkan pemutusan kerja bagi masyarakat. Rangkaian hal tersebut menjadi stresos yang sangat besar bagi kebanyakan masyaraka perekonomian menengah kebawah. Ditambah dengan stressor dari ketakutan warga tertular virus COVID-19 dan terbantasnya aktifitas masyarakat karena diberlakukannya PSBB mengakibatkan tambahan stressor bagi masyarakat (Praveena, Gangadhar and Ratnam, 2020).

Benyaknya stressor yang muncul dapat mempengaruhi sistem imun di masyarakat. Manajemen stress yang baik bagi masyarakt diperlukan untuk mengelola stress dalam keadaan pandemic COVID-19 seperti saat ini (Newman and Lattouf, 2020).Peran perawat untuk melalukan pendidikan kesehatan dalam mengelola stress masyarakat sangat diperlukan supaya masyarakat lebih tahan saat mengalami keadan buruk seperti saat ini.

\section{METODE}

Pengabdian kepada masyarakat yang dilakukan oleh pengabdi menggunakan metode jarak jauh. Pengabdi menyiapkan sebuah vidio yang berisi pendidikan kesehatan mengenai manajemen stresss dan berupa pendidikan kesehatan kepada SMA yang menjadi aktifis PMR di SMA N 1 Suberpucung kota malang.

Persiapan yang dilakukan dengan menyiapkan materi dan menyusun proposal mengenai pelaksanaan pelatihan BHD. Selain itu pengabdi melakukan koordinasi untuk persiapan pelaksanaan pelatihan tersebut.
Pengabdian kepada masyarakat ini diawali dengan penentuan tempat kegiatan dan pengkajian permasalahan yang dialami. Setelah permasalahan telah ditemukan, dilanjutkan dengan pengurusan perijinan untuk dapat melakukan pengabdin kepada masyarakat di SMA N 1 Sumberpucung. Setelah itu dimulai dengan pertemuan awal, pendidikan kesehatan.

Pengabdian yang dilaksanakan diawali kontrak dengan siswa untuk pelaksanaan pelatihan Bantuan Hidup Dasar. Sebelum memberikan pendidikan kesehatan, peneliti membagikan kuesioner mengenai bantuan hidup dasar kepada pasara siswa. Jika sudah, peneliti membagi menjadi dua kelompok. Kelompok pertama diberikan pendidikan BHD dan diberikan video BHD dan kelompok kedua hanya diberikan pendidikan BHD. Setelah semua selesai pengabdi memberikan kuesioner post tes.

Pengabdian melakukan kontrak dengan siswa untuk pelaksanaan pelatihan Bantuan Hidup Dasar. Sebelum memberikan pendidikan kesehatan, peneliti membagikan kuesioner mengenai bantuan hidup dasar kepada pasara siswa. Jika sudah, peneliti membagi menjadi dua kelompok. Kelompok pertama diberikan pendidikan BHD dan diberikan video BHD dan kelompok kedua hanya diberikan pendidikan BHD. Setelah semua selesai pengabdi memberikan kuesioner post tes.

\section{HASIL dan PEMBAHASAN}

Pendidikan kesehatan yang dilakukan di SMA N 1 Sumberpucung merupakan pendidikan Bantuan Hidup Dasar dan Pertolongan pertama pada kecelakaan. Materi bantuang hidup dasar dilakukan untuk menolong pasien sehingga terhindar dari kematian. Rantai pertolongan atau kelangsungan hidup 
sangat dilakukan untuk memberikan pertolongan kepada pasien.

Rantai kelangsungan hidup dimulai saat kita melihat orang yang di duga mengalami henti jantung. Langkah pertama dengan aktivasi respon gawat darurat. Aktivasi ini dengan menghubungi Ambulan Gawat Darurat 118 ataupun menghubungi rumah sakit dengan fasilitas gawat ambulan. Hal selanjutnya yang harus dilakukan by stander adalah melakukan CPR dengan kualitas tinggi. CPR kualitas tinggi dengan kedalaman rata-rata $5 \mathrm{~cm}$ dengan kecepatan 100-120 kali per menit (Nugroho and Sucipto, 2020b). CPR terus dilakukan terus menerus sampai sampai terjadi beberapa indikasi seperti penolong kelelahan dan sampai bantuan yang lebih advance datang.

Saat ambulan telah datang, pertolongan dialihkan kepada tenaga medis oleh ambulan (Nugroho and Sucipto, 2020a). Saat ditolong oleh petugas ambulan, siklus beralih dengan algoritma CPR seperti gambar 2.2. Setelah pasien sudah memungkinkan untuk dipindahkan, makan pasien dilakukan pemindahan menuju rumah sakit ataupun pada pelayanan devinitif. Saat di rumah sakit, pasien diberikan pelayanan intersive sampai pasien dapat pulih.

Selain itu dalam pertolongan pertama di luar rumah sakit perlu beberapa hal yang haru disiapkan. Saat akan melakukan pertolongan pastikan pemeriksaan lingkungan (Morrison et $a l ., 2016)$. Lihat luar lingkunan apakah aman untuk memberikan pertolongan pertama. Moto yang digunakan dalam pertolongan di luar rumah sakit adalah “ Aman diri, Aman Pasien, Aman Lingkungan". Prioritas pertama pastikan penolong aman, agar tidak menambah korban (Nugroho, Soeharto and Utami, 2019).

Selama pandemi COVID-19 telah menjadi wabah global sejak desember 2019 dan sampai sekarang belum ada tanda-tanda wabah ini akan berakhir (Praveena, Gangadhar and Ratnam, 2020). Wabah ini berdampak bagi seluruh sendi kehidupan masyarakat, termasuk bagi siswa SMA. Salah satunya di SMA N 1 Sumber Pucung yang tetap melaksanakan perkuliahan secara daring Pelaksanaan pelatihan hidup dasar yang dilakukan oleh staf civitas STIKes Panti Waluya juga dilakukan melalui media daring yaitu zoom.

Pelatihan bantuan hidup dasar yang dilakukan merupakan pelatihan bagi siswa SMA khususnya bagi siswa yang mengikuti Palang Merah Remaja (PMR). Pelatihan merupakan apelatihan bantuan hidup dasar seperti pertolongan pertama pada kecelakaan, balut luka dan pertolongan pertama untuk orang dengan keadaan gawat darurat (Hurley et al., 2020).

Pelatihan ini dilakukan bagi siswa PMR supaya mereka dapat menjadi agen of change bagi masyarakat. Siswa PMR ini dapat melatihkan bantuan hidup dasar bagi orang sekitar dan bagi masyarakat. Sehingga kesadaran masyarakat mengenai pertolongan keadaan gawat darurat semakin meningkat. Dengan adanya pelatihan ini diharapkan masyarakat menjadi lebih sadar dan waspada dalam memberikan pertolongan pertama, supaya pertolongan yang diberikan menjadi lebih efektif dan aman bagi pasien ataupun bagi penolong itu sendiri.

Respon positif tersebut dapat diartikan bahwa pengabdian kepada masyarakatpendidikan dan pelatihan hidup dasar bagi ssiwa SMA N 1 Sumberpucung dapat diterima dengan baik. Ada beberapa saran dari komunitas masyarakat untuk mengembangkan pelaihan tersebut menggunakan metode yang lebih alternatif. Diharapkan lagi akan dilakukan metode pengabdian masyarkat dengan metode interaktif tanpa mengesampingkan protocol kesehatan. 


\section{KESIMPULAN DAN SARAN}

Pelaksanaan kegiatan Pengabdian Kepada Masyarakat di SMA N 1 Sumber Pucung Kabutapaten Malang dilakukan dengan metode daring. Kegiatan PkM mengenai pelatihan bantuan hidup dasar bagi siswa SMA ini dilakukan dengan peserta anggota PMR di SMAN 1 Sumber Pucung. Kegiatan mendapatkan sambutan positif bagi seluruh peserta, tetapi ada beberapa kelamahan saat melakukan kegiatan PkM ini, adalah kegiatan dilakukan melalui media daring. Media daring yang digunakan menggunakan media ZOOOM, sehingga interaksi berjalan kurang maksimal.

Seiring perkembangan teknologi, diharapkan pendidikan kesehatan dapat dilakukan menggunakan cara yang lebih menarik. Pemberian pengabdian kepada masyarakat melalui video, games ataupun aplikasi yang lebih komunikatif diharapkan bisa meningkatkan minat masyarakat. Ditambah lagi dengan keadaan pandemic COVID-19, diperlukan protocol kesehatan yang ketat, sehingga membatasi perkumpulan masa. Pelaksanaan menggunakan media yang lebih interaktif diharapkan dapat meningkatkan antusias peserta kegiatan PkM.

\section{DAFTAR PUSTAKA}

Hurley, J. et al. (2020) 'Emotional intelligence as a mechanism to build resilience and non-technical skills in undergraduate nurses undertaking clinical placement', International Journal of Mental Health Nursing, 29(1), pp. 47-55. doi: 10.1111/inm.12607.

Lontoh, C., Kiling, M. and Wongkar, D. (2013) 'Pengaruh Pelatihan Teori Bantuan Hidup Dasar Terhadap
Pengetahuan Resusitasi Jantung Paru Siswa-Siswi Sma Negeri 1 Toili', Jurnal Keperawatan UNSRAT, 1(1), p. 111914.

Morrison, J. J. et al. (2016) 'The epidemiology of Scottish trauma: A comparison of pre-hospital and inhospital deaths, 2000 to 2011', Surgeon. Elsevier Ltd, 14(1), pp. 1-6. doi: 10.1016/j.surge.2015.02.001.

Nasution, R. E. P. (2017) Panduan Bantuan Hidup Dasar dan Pertolongan Pertama Pada Luka. Jakarta: Whitecoathunter.

Newman, N. A. and Lattouf, O. M. (2020) 'Coalition for medical education-A call to action: A proposition to adapt clinical medical education to meet the needs of students and other healthcare learners during COVID-19', Journal of Cardiac Surgery, 35(6), pp. 1174-1175. doi: 10.1111/jocs. 14590 .

Nugroho, K. D., Soeharto, S. and Utami, Y. W. (2019) 'Factors related to competence in prehospital care', Indian Journal of Public Health Research and Development, 10(9), pp. 735-740. doi: 10.5958/0976-5506.2019.02522.1.

Nugroho, K. D. and Sucipto, U. (2020a) 'PHENOMENOLOGY STUDY: CHANGE IN THE PERCEPTION OF CANCER PATIENTS DUE TO FAMILY SUPPORTS', WORLD JOURNAL OF ADVANCE HEALTHCARE RESEARCH, 4(3).

Nugroho, K. D. and Sucipto, U. (2020b) 'Studi Fenomenologi: Dampak Pengabaian Gejala Kanker Bagi Klien Dan Keluarga', Jurnal Keperawatan Malang, 5(1), pp. 46-54. doi: 10.13841/j.cnki.jxsj.2013.01.021.

Praveena, P. B. G., Gangadhar, M. and Ratnam, K. V. (2020) 'International Journal of Medical Science and Dental 
Research Effectiveness of e- learning among college students on knowledge regarding COVID - 19', 03(02), pp. 718.

Presiden Republik Indonesia (2020) Peraturan Pemerintah Nomor 21 Tahun 2020 tentang Pembatasan Sosial Berskala Besar Dalam Rangka Percepatan Penanganan Coronavirus Disease 2019/COVID-19. Jakarta: Republik Indonesia.

Putri, N. O., Barlianto, W. and Setyoadi (2019) 'The influence of learning with mobile application in improving knowledge about basic life support', Indian Journal of Public Health Research and Development, 10(8), pp. 1010-1014. doi: 10.5958/09765506.2019.02028.X.

WHO (2020) Coronavirus disease (COVID-19) pandemic, Word Health Organization. 